UCRL-JC-118901

PREPRINT

\title{
Stabilization of Inorganic Mixed Waste to Pass the TCLP and STLC Tests Using Clay and pH-Insensitive Additives
}

\author{
John S. Bowers* \\ Jim R. Anson \\ Socorro M. Painter \\ Rocco E. Maitino
}

This paper was prepared for submittal to

HAZMACON '95

San Jose, $C A$

April 4-6, 1995

March 1995

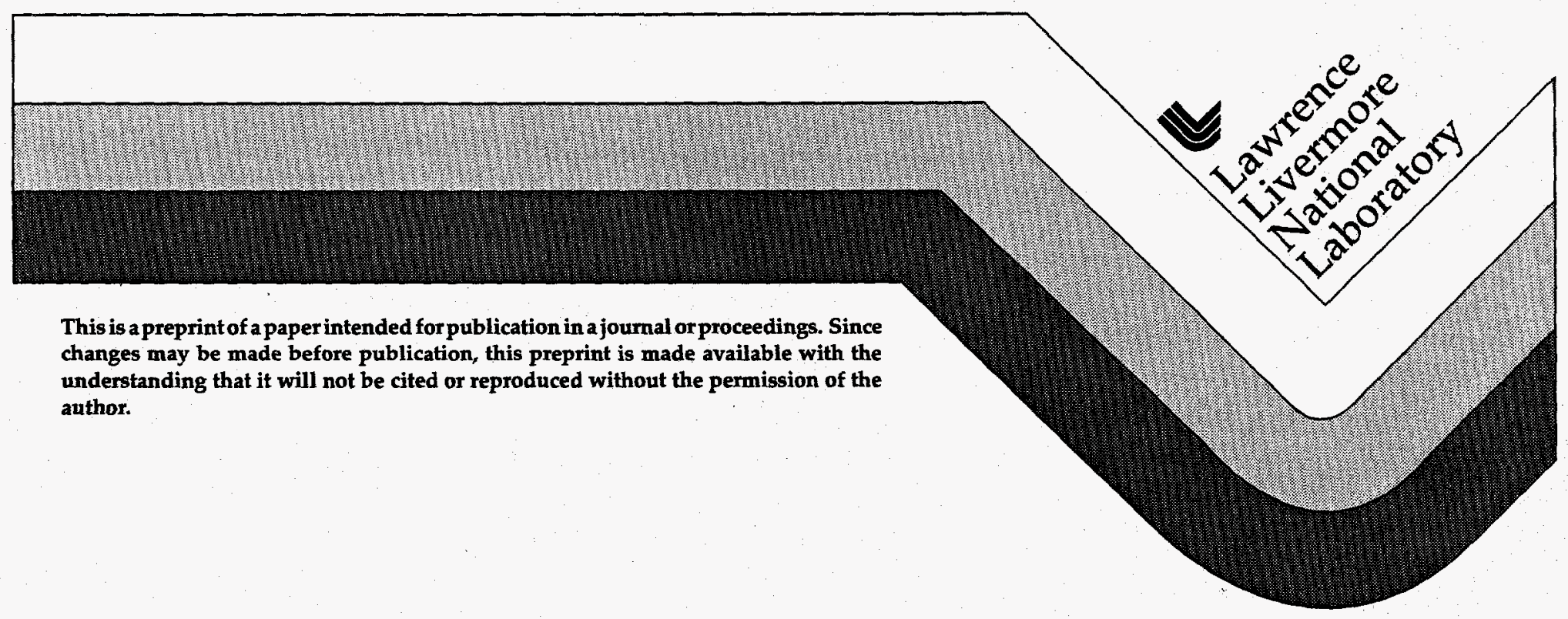




\section{DISCLAIMER}

This document was prepared as an account of work sponsored by an agency of the United States Government. Neither the United States Government nor the University of California nor any of their employees, makes any warranty, express or implied, or assumes any legal liability or responsibility for the accuracy, completeness, or usefulness of any information, apparatus, product, or process disclosed, or represents that its use would not infringe privately owned rights. Reference herein to any specific commercial product, process, or service by trade name, trademark, manufacturer, or otherwise, does not necessarily constitute or imply its endorsement, recommendation, or favoring by the United States Government or the University of California. The views and opinions of authors expressed herein do not necessarily state or reflect those of the United States Government or the University of California, and shall not be used for advertising or product endorsement purposes. 


\section{DISCLAIMER}

Portions of this document may be illegible in electronic image products. Images are produced from the best available original document. 


\title{
STABILIZATION OF INORGANIC MIXED WASTE TO PASS THE TCLP AND STLC TESTS USING CLAY AND pH-INSENSITIVE ADDITIVES
}

\author{
John S. Bowers* \\ Jim R. Anson \\ Socorro M. Painter \\ Rocco E. Maitino \\ Hazardous Waste Management Division \\ Lawrence Livermore National Laboratory \\ P. O. Box 808, L-621 \\ Livermore, CA 94550 \\ (510) 423-7756 (phone) \\ (510) 422-3469 (fax)
}

\section{DISCLAIMER}

\begin{abstract}
This report was prepared as an account of work sponsored by an agency of the United States Government. Neither the United States Government nor any agency thereof, nor any of their employees, makes any warranty, express or implied, or assumes any legal liability or responsibility for the accuracy, completeness, or usefulness of any information, apparatus, product, or process disclosed, or represents that its use would not infringe privately owned rights. Reference herein to any specific commercial product, process, or service by trade name, trademark, manufacturer, or otherwise does not necessarily constitute or imply its endorsement, recommendation, or favoring by the United States Government or any agency thereof. The views and opinions of authors expressed herein do not necessarily state or reflect those of the United States Government or any agency thereof.
\end{abstract}




\title{
STABILIZATION OF INORGANIC MIXED WASTE TO PASS THE TCLP AND STLC TESTS USING CLAY AND pH-INSENSITIVE ADDITIVES
}

\begin{abstract}
Stabilization is a best demonstrated available technology, or BDAT, as defined by the U. S. Environmental Protection Agency (EPA) in Title 40, part 268, of the Code of Federal Regulations (40 CFR 268). This technology traps toxic contaminants (usually both chemically and physically) in a matrix so that they do not leach into the environment. Typical contaminants that are trapped by stabilization are metals (mostly transition metals) that exhibit the characteristic of toxicity as defined by 40 CFR part 261 . The stabilization process routinely uses pozzolanic materials. Portland cement, fly ashlime mixes, gypsum cements, and clays are some of the most common materials. They are inexpensive, easy to use, and effective for wastes containing low concentrations of toxic materials.
\end{abstract}

In many instances, materials that can pass the Toxicity Characteristic Leaching Procedure (TCLP-the federal leach test) or the Soluble Threshold Leachate Concentration (STLC-the California leach test) must have high concentrations of lime or other caustic material because of the low $\mathrm{pH}$ of the leaching media. Both leaching media, California's and EPA's, have a pH of 5.0. California uses citric acid and sodium citrate while EPA uses acetic acid and sodium acetate-the concentration in the leachate is approximately ten times higher for the STLC procedure than the TCLP. These media can form ligands that provide excellent metal leaching. Because of the aggressive nature of the leaching medium, stabilized wastes in many cases will not pass the leaching tests.

At the Lawrence Livermore National Laboratory (LLNL), additives such as dithiocarbamates and thiocarbonates, which are $\mathrm{pH}$-insensitive and provide resistance to ligand formation, are used in the waste stabilization process. Attapulgite, montmorillonite, and sepiolite clays are used because they are forgiving (recipe can be adjusted before the matrix hardens) when formulating a stabilization matrix, and they have a neutral $\mathrm{pH}$.

By using these clays and additives, LLNL's highly concentrated wastewater treatment sludges have passed the TCLP and STLC tests. The most frequently used stabilization process consists of a customized recipe involving waste sludge, clay and dithiocarbamate salt, mixed with a double planetary mixer into a pasty consistency. TCLP and STLC data on this waste matrix have shown that the process matrix meets land disposal requirements.

\section{BACKGROUND}

The disposal of low-level mixed waste must meet land disposal restrictions under the federal regulations (40 CFR 268). For this reason, LLNL's Environmental Protection Department has undertaken waste stabilization, deeming it to be the BDAT for waste disposal that adheres to regulations.

To assure that stabilization technology is effective, the processed material must undergo the regulatory leach tests, which are Toxicity Characteristic Leaching Procedure 
(TCLP) and the California Assessment Manual Waste Extraction Test for Soluble Threshold Leachate Concentration (CAM-WET STLC). The CAM-WET is a much more aggressive test, applying to many more constituents, and frequently requires verification of success and customization in stabilization processes.

Currently, mixed wastes that exhibit the characteristics of corrosivity (D002), low total organic carbon (TOC) ignitability (D001), or toxicity for pesticides (D012 through D017) must be treated for all underlying constituents to meet land disposal requirements. Table 1 summarizes regulatory threshold limits for metals, their EPA codes, and underlying constituents.

The waste requiring stabilization at LLNL is filter-aid sludge from processing wastewaters generated through various systems within the LLNL site. This filter-aid sludge does not exhibit characteristics that require LLNL to treat underlying constituents. However, to dispose of the waste at the Nevada Test Site, State of California regulations apply, and these require LLNL to pass the STLC test. The metals analyzed in the STLC are the same as the underlying constituents in EPA's Universal Treatment Standard (40 CFR 268.48).

EPA recognizes that stabilization is a BDAT. Therefore, it does not require stabilized wastes to be sampled to verify that they meet land disposal restrictions. However, the Nevada Test Site requires verification of $10 \%$ of the LLNL low-level wastes sent there for disposal. For this waste, TCLP extract concentrations and the STLCs are applied for those waste constituents listed in the Constituent Concentrations In Waste Extract (CCWE) table (40 CFR 268.41). Table 2 lists the metals analyzed and the CAM-WET threshold limit for hazardous waste.

The Nevada Test Site also requires that California constituent radioactive wastes be treated prior to disposal. LLNL's work with California constituents will help in developing techniques to meet the universal treatment standards when promulgation requires treatment of underlying constituents for metal characteristic codes. The differences between the federal (TCLP) and the California State (STLC) leaching tests are subtle but provide substantial differences in test results. The differences in these tests for the stabilized wastes are summarized in Table 3.

Table 3 shows that the California State leaching test is more rigorous in all categories except $\mathrm{pH}$ and extraction fluid weight ratio. The citrate buffer it uses has greater soluble ligand formation properties than does the acetate buffer used in the federal test. Both anions form soluble complexes with metals, but citrate has much larger formation constants and can form bidentates and tridentates with metals in the presence of hydrogen (as in a pH of 5.0). Both buffer strengths are the same for this type of waste. Wastes that are not pasty are ground up to a certain particle size. The particle size for the STLC is five times smaller than for the TCLP, providing the STLC with a steeper internal diffusion gradient. The leachate time for STLC is longer, so more contaminants leach out. Although there is twice as much extraction fluid in the TCLP, this may not be significant. While more fluid provides for a larger diffusion driving force, this is not significant for lower concentrations (parts per million range). 
Table 1. Metal Constituents, Characteristic Codes, and Federal Regulatory Threshold Limits.

\begin{tabular}{|l|l|c|c|}
\hline $\begin{array}{l}\text { Metal } \\
\text { Constituent }\end{array}$ & $\begin{array}{l}\text { Characteristic } \\
\text { EPA Code }\end{array}$ & $\begin{array}{l}\text { TCLP(mg/L) } \\
\text { Regulatory } \\
\text { Levels }\end{array}$ & $\begin{array}{l}\text { TCLP(mg/L) under } \\
\text { Universal Treatment } \\
\text { Standards }\end{array}$ \\
\hline Antimony & N/A & N/A & 2.1 \\
\hline Arsenic & D004 & 5 & 5 \\
\hline Barium & D005 & 100 & 7.6 \\
\hline Beryllium & N/A & N/A & 0.014 \\
\hline Cadmium & D006 & 1.0 & 0.19 \\
\hline Chromium & D007 & 5.0 & 0.86 \\
\hline Lead & D008 & 5.0 & 0.37 \\
\hline Mercury (retort) & D009 & 0.2 & 0.2 \\
\hline Mercury (other) & D009 & 0.2 & 0.025 \\
\hline Nickel & N/A & N/A & 5.0 \\
\hline Selenium & D010 & 1.0 & 0.16 \\
\hline Silver & D011 & 5.0 & 0.3 \\
\hline Thallium & N/A & N/A & 0.078 \\
\hline Vanadium & N/A & N/A & 0.23 \\
\hline Zinc & N/A & N/A & 5.3 \\
\hline
\end{tabular}

Table 2. Metal Constituents and California Regulatory Threshold Limits.

\begin{tabular}{|l|c|}
\hline Metal Constituent & $\begin{array}{l}\text { CAM - WET STLC } \\
\text { Threshold Limits } \\
\text { (mg/L) }\end{array}$ \\
\hline Antimony & 15 \\
\hline Arsenic & 5.0 \\
\hline Barium & 100 \\
\hline Beryllium & 0.75 \\
\hline Cadmium & 1.0 \\
\hline Chromium & 5.0 \\
\hline Cobalt & 80 \\
\hline Copper & 25 \\
\hline Lead & 5.0 \\
\hline Mercury & 0.2 \\
\hline Molybdenum & 350 \\
\hline Nickel & 20 \\
\hline Selenium & 1.0 \\
\hline Silver & 5.0 \\
\hline Thallium & 7.0 \\
\hline Vanadium & 24 \\
\hline Zinc & 250 \\
\hline
\end{tabular}

\section{RAW WASTE CHARACTERIZATION}

The waste to be stabilized originates as aqueous waste. The metal constituents in the wastes are precipitated predominantly with hydroxide ion. The waste is then filtered through a rotary-drum vacuum-filter to remove the hydroxide precipitate, which is 
Table 3. Comparison of Federal and California State Leaching Tests.

\begin{tabular}{|l|l|l|}
\hline Criterion & TCLP (Federal) & STLC (California) \\
\hline Extraction Fluid Type & Acetate buffer & Citrate buffer \\
\hline Approx. Extraction Fluid pH & 5 & 5 \\
\hline Approx. Solids Diameter (Max.) & 0.01 meters & 0.002 meters \\
\hline Leaching Time & 18 hours & 48 hours \\
\hline Extraction Fluid Weight Ratio & $20: 1$ & $10: 1$ \\
\hline
\end{tabular}

trapped by diatomaceous earth (filter-aid). This spent filter-aid sludge is periodically cut from the rotary drum during the aqueous waste treatment process and sent to LLNL's processing building for stabilization. The sludge contains about $60 \%$ water, with the balance of the material being diatomaceous earth, metal contamination, and often organics such as oil and carbon. The metal contamination in the sludge varies widely from batch to batch, since the waste streams processed are widely varied. Typically, one $5-\mathrm{m}^{3}$ aqueous waste batch will yield one to two $0.2-\mathrm{m}^{3}$ drums of diatomaceous earth waste. A typical example of the filter-aid sludge in a drum that requires stabilization is given in Table 4.

The diatomaceous earth waste itself has little resistance against either the federal or California leaching test. This is to be expected since hydroxide precipitates cannot hold up against any mild acid buffer regardless of their ability to form soluble complexes with metals. Metal hydroxide solubilities can be calculated from first principles using hydroxide formation constants, solubility products, and assuming unity for activity coefficients. Cadmium, lead, and zinc appear to be completely soluble at a pH of 5 .

Table 4 demonstrates the wide variety of metal constituents found in the filter-aid sludge. The highest in the subset shown is nickel at $2,076 \mathrm{mg} / \mathrm{kg}$. Usually the largest concentration of metal contamination in the waste sludge does not exceed $5,000 \mathrm{mg} / \mathrm{kg}$. The more concentrated sludges at LLNL are from spent plating baths (electro and electroless plating), which seldom contain arsenic, antimony, and selenium. These metals usually have to be precipitated as anion complexes and ion-exchanged prior to filtration because they will not precipitate as a hydroxide. Fortunately, LLNL does not see much of these metal contaminants.

\section{THE CLAY MATRIX USED IN STABLIZATION}

The primary clays used in LLNL's stabilization process are sepiolite, montmorillonite, and attapulgite. These clays have defined alumina or magnesium oxidesilica layers upon hydration. These clays were chosen because they have demonstrated effective stabilization in TCLP testing. They also tend not to increase the total waste volume to the extent that other clays (e.g., bentonite clay) do.

The clays also possess the ability to hydrate and adsorb hazardous constituents. They form thixotropic fluids when hydrated and have minimal compression strength, but are considered solids from a regulatory standpoint (they pass the EPA SW846 9095, Paint Filter Liquids Test).

Montmorillonites are impure forms of $\mathrm{Al}_{2} \mathrm{O}_{3} \cdot 4 \mathrm{SiO}_{2} \cdot \mathrm{H}_{2} \mathrm{O}$. The impurities are magnesium, potassium, calcium, titanium, and iron. The clay is an expanding type which forms a smectite when hydrated. Its structure consists of an aluminum hydroxide octahedral in between two sheets of silica tetrahedral. During the formation of the clay, 
Table 4. Typical Diatomaceous Earth Sludge Batches.

\begin{tabular}{|l|l|l|l|l|}
\hline Analysis Type: & mass balance & mass balance & mass balance & mass balance \\
\hline Batch Number: & $92-06$ & $92-15$ & $92-20$ & $92-32$ AT/A \\
\hline Sample Number: & N/A & N/A & N/A & N/A \\
\hline Mass, kg: & 246 & 143 & 90 & 50 \\
\hline $\begin{array}{l}\text { CAM-WET Metals, } \\
\text { mg/kg: }\end{array}$ & & & & \\
Antimony & - & - & - & - \\
\hline Arsenic & 0.0 & 0.2 & 1.6 & - \\
\hline Barium & 79.0 & 4.4 & 11.7 & - \\
\hline Beryllium & 34.0 & - & - & - \\
\hline Cadmium & - & 11.0 & - & - \\
\hline Chromium & 252.5 & 126.0 & 81.8 & 4.0 \\
\hline Cobalt & 0.0 & - & - & 31.7 \\
\hline Copper & 389.0 & 779.6 & 294.4 & 245.7 \\
\hline Lead & 183.0 & 52.4 & - & - \\
\hline Manganese & 111.5 & 40.4 & 517.0 & - \\
\hline Mercury & 35.4 & 0.2 & 0.0 & - \\
\hline Molybdenum & 0.0 & 26.3 & 5.4 & 114.9 \\
\hline Nickel & 96.9 & 2076.4 & 58.5 & 83.2 \\
\hline Selenium & - & 0.1 & - & - \\
\hline Silver & 42.6 & - & 42.6 & - \\
\hline Thallium & - & - & - & - \\
\hline Vanadium & 0.7 & 20.9 & 0.7 & 114.9 \\
\hline Zinc & 144.9 & - & 750.0 & 107.0 \\
\hline Rad Analysis, Bq/kg: & & & & \\
alpha & 232 & - & 110 & 6.5 \\
\hline beta & 6.9 & - & 139 & 2.2 \\
\hline tritium & 4.4 & 0.126 & 14.1 & 1.8 \\
\hline & & & & \\
\hline
\end{tabular}

cationic impurities disrupt the clay matrix by replacing the alumina ions. This is most profound when the two aligning tetrahedrals (above and below the octahedral) have substituted alumina for other metal oxides. In the case of this clay, the replacement cations have a less positive charge than the alumina. This results in a net negative charge in the clay lattice, giving it the ability to hold cations in place, or "sorb" them. The hydration reaction in its simplest view is given below.

$$
\mathrm{Al}_{2} \mathrm{O}_{3} \cdot 4 \mathrm{SiO}_{2} \cdot \mathrm{H}_{2} \mathrm{O}+2 \mathrm{H}_{2} \mathrm{O} \rightarrow 2\left[\mathrm{SiO}_{2} \cdot \mathrm{Al}\left(\mathrm{OH}_{3}\right) \cdot \mathrm{SiO}_{2}\right]
$$

Attapulgites and sepiolites have a similar behavior to montmorillonite but their structures are different. Attapulgite and sepiolite are not just alumina sandwiched between silica. They have a ribbon-like structure in which alternating twists in the ribbon are silica and metal oxides. The structure is stable and replacement of the metal oxides is less evident than in montmorillonite. This gives less adsorption capacity but provides a lower expansion upon hydration. The chemical composition of attapulgite and sepiolite is given below.

Attapulgite: $(\mathrm{Mg})_{5} \mathrm{Si}_{8} \mathrm{O}_{20}(\mathrm{OH})_{2}\left(\mathrm{OH}_{2}\right)_{4} \cdot 4 \mathrm{H}_{2} \mathrm{O}$

Sepiolite: $(\mathrm{Mg})_{9} \mathrm{Si}_{12} \mathrm{O}_{30}(\mathrm{OH})_{6}\left(\mathrm{OH}_{2}\right)_{4} \cdot 6 \mathrm{H}_{2} \mathrm{O}$ 
These formula are based on the Nagy and Bradley model and are discussed in Weaver (1975). The clays contain aluminum as an impurity but at a much lower volume than magnesium.

\section{pH-INSENSITIVE ADDITIVES}

Because $\mathrm{pH}$, complex formation, and diffusion are the primary driving forces for leaching in the TCLP and STLC tests, it is important to limit these phenomena as much as possible.

The instance of molecular diffusion, although modeled in many situations and scenarios (sometimes in very complex detail), is small in this waste stabilization case. The diffusion of interest is between two solid phases: a successfully precipitated metal that is physisorbed to an active site, diffusing through a layer of clay. The potential of such a case is orders of magnitude smaller than solid-liquid phase diffusion.

The chance for complex formation between a citrate and metal is also relatively small. The formation constants of the bidentates and tridentates are orders of magnitude smaller than most inorganic solubility products. Acetate salt formation is an even smaller possibility. Hydroxide precipitates do not hold up well against the mild acid buffers of the leaching tests.

However, the use of $\mathrm{pH}$-insensitive additives is required when high concentrations of metals are found in the waste sludge. There are many precipitating agents marketed under a variety of names; they are usually sold for wastewater treatment. The primary non-hydroxide chemicals sold for precipitation are iron and sodium sulfide, thiocarbamate, and thiocarbonate. These chemicals are all relatively $\mathrm{pH}$-insensitive but still work better in alkaline solutions or high lime concentrations. The solubility products of sulfide or sulfur-bearing organic salts are all much lower than hydroxides. Care must be taken in using these materials because they are toxic in their own right.

\section{MIXING EQUIPMENT}

This process uses a double planetary, open paddle mixer. It is a "change-can" mixing device that uses a standard 55-gal $\left(0.2-\mathrm{m}^{3}\right)$ drum as the mixing vessel or changecan. Its power source is a 15 -hp $(11,200-\mathrm{W})$, totally enclosed fan-cooled (TEFC) motor operating at $1,800 \mathrm{rpm}$. The motor shaft is connected to a worm that reduces speed by 40:1. The worm gear is attached to a shaft that is itself attached to a flat circular gear engaging two other gears, attached to each other and floating freely about the center shaft. These two gears each have a shaft attached to an open paddle. When the central shaft turns clockwise, the two opposing gears and their paddles spin counterclockwise. At the same time that the two paddles spin counterclockwise about their own axis, they spin together clockwise about the center gear. Thus, each paddle behaves as a planet spinning on axis, rotating around the sun (center gear). All three gears are approximately the same size and thus spin at about $45 \mathrm{rpm}$. This would appear slow (less than 1 revolution per second) if one did not see three motions occurring at once.

This mixing action is needed because the clay and diatomaceous earth mixture is a thixotropic pseudoplastic. It has extremely high viscosity until a high shear is applied, and it is a free-standing monolith when it is not being forced to move. Low speed, high shear mixing is more appropriate for this type of material than high speed, low shear mixing. 


\section{PROCESS DESCRIPTION}

The stabilization process is implemented making use of water already present in the diatomaceous earth sludge. Stabilizer is added in an amount calculated to solidify the water in the sludge, not the entire weight of the sludge. Initially, much of the preliminary stabilization product was too soupy due to addition of too much water to the sludge. Now, a moisture determination is made before stabilization begins. This is performed in a standard laboratory oven at approximately $600^{\circ} \mathrm{C}$ and 600 grams of waste. The average moisture content is about $55 \%$, varying between $33 \%$ and $80 \%$, depending on the aqueous waste treated. The amount of clay added to the waste is determined by using the following formula:

$$
\text { where } \begin{aligned}
M & =(0.6)(\mathrm{X})(\mathrm{Z}), \\
\mathrm{M} & =\text { mass of clay to add, } \\
\mathrm{X} & =\text { mass fraction of water in the waste, } \\
\mathrm{Z} & =\text { mass of waste sludge. }
\end{aligned}
$$

This formula gives a consistent, stiff matrix. It allows for easy cleaning of the equipment because the clay matrix sticks to itself much more than to the open paddles. Also, it does not dehydrate readily when sealed in a drum to cure.

Additives are used when metal concentrations are too high for the clay alone. In such instances, clay alone provides little fixation. Table 5 shows the original raw material concentrations of metals with the STLC values after stabilization. A fair comparison can be made if one takes the STLC value, multiplies it by 10 (this is the dilution caused by the citrate buffer), then multiples by the ratio of stabilized net mass to mass balance net mass. This will show that fixation does not occur in many cases and dilution is the main effect (the Table 5 values for zinc demonstrate this). Figure 1 shows a good way to present data to demonstrate the fixation of a metal constituent. The total constituent mass is calculated, then the percentage of the amount of metal leached is calculated. A direct comparison of the amount leached in the original waste form and the stabilized waste form can then be made.

\section{PROCESS ANALYSIS}

Figure 1 shows the results of stabilization with clay only. For many metals at moderate concentrations, fixation with clay is adequate. Cadmium and cobalt show an order of magnitude reduction in leachate concentration upon stabilization with clay only. Nickel shows greater than one order of magnitude reduction and copper shows varying reductions in leachate concentration up to two orders of magnitude.

If the waste sludge contains greater than a few hundred grams of the metals mentioned above or contains metals such as chromium, molybdenum, vanadium, and zinc, additives are required to perform the stabilization successfully. Additives were first added at stoichiometric ratios plus $10 \%$ excess. This proved unsuccessful. Often, stabilization was not successful unless 100 times stoichiometry was used. Currently, $12 \%$ by weight of waste is used and only dithiocarbamate (DTC) has been successful at this concentration.

LLNL found that the sequence of stabilization is very important and that two mixing stages are needed. First, the $\mathrm{pH}$-insensitive precipitating agent is added, and the waste sludge and additive are allowed to mix. The mixing continues for two to five 
Table 5. Results of a Few Stabilized Wastes, Using Only Clay (Mass Balance, Total Constituent Concentrations, Stabilized, STLC Values).

\begin{tabular}{|c|c|c|c|c|c|c|c|c|}
\hline $\begin{array}{l}\text { Analysis } \\
\text { Type: }\end{array}$ & $\begin{array}{l}\text { mass } \\
\text { balance }\end{array}$ & stabilized & $\begin{array}{l}\text { mass } \\
\text { balance }\end{array}$ & stabilized & $\begin{array}{l}\text { mass } \\
\text { balance }\end{array}$ & stabilized & $\begin{array}{l}\text { mass } \\
\text { balance }\end{array}$ & stabilized \\
\hline $\begin{array}{l}\text { Batch } \\
\text { Number: }\end{array}$ & \begin{tabular}{|l|}
$92-28$ \\
$\mathrm{AT}$
\end{tabular} & $\begin{array}{l}92-28 \\
\mathrm{AT}\end{array}$ & $\begin{array}{l}92-33 \\
\text { AT/A }\end{array}$ & $\begin{array}{l}92-33 \\
\text { AT/A }\end{array}$ & $\begin{array}{l}92-35 \\
\text { AT/A }\end{array}$ & $\begin{array}{l}92-35 \\
\text { AT/A }\end{array}$ & $\begin{array}{l}92-36 \\
\text { AT/A }\end{array}$ & $\begin{array}{l}92-36 \\
\text { AT/A }\end{array}$ \\
\hline Sample No.: & $\mathrm{N} / \mathrm{A}$ & 9401764 & N/A & 9401740 & N/A & 9401677 & N/A & 9401765 \\
\hline $\begin{array}{l}\text { Net Waste } \\
\text { Mass (kg): }\end{array}$ & 80 & 132 & 55 & 91 & 85 & 153 & 64.5 & 157 \\
\hline $\begin{array}{l}\text { CAM-WET } \\
\text { Metals: }\end{array}$ & $\mathrm{mg} / \mathrm{kg}$ & $\begin{array}{l}\mathrm{mg} / \mathrm{L} \\
(\mathrm{ppm})\end{array}$ & $\mathrm{mg} / \mathrm{kg}$ & $\begin{array}{l}\mathrm{mg} / \mathrm{L} \\
(\mathrm{ppm})\end{array}$ & $\mathrm{mg} / \mathrm{kg}$ & $\begin{array}{l}\mathrm{mg} / \mathrm{L} \\
(\mathrm{ppm})\end{array}$ & $\mathrm{mg} / \mathrm{kg}$ & $\begin{array}{l}\mathrm{mg} / \mathrm{L} \\
(\mathrm{ppm})\end{array}$ \\
\hline Antimony & - & $\mathrm{ND}$ & - & $\mathrm{ND}$ & - & ND & - & 0.18 \\
\hline Arsenic & - & ND & - & ND & - & ND & - & 0.21 \\
\hline Barium & - & 2.9 & 6.43 & 2.4 & 5.94 & 2.7 & 3.31 & 1.96 \\
\hline Beryllium & - & 0.086 & - & 0.22 & - & 0.1 & - & 0.09 \\
\hline Cadmium & - & $\mathrm{ND}$ & - & ND & - & $\mathrm{ND}$ & - & 0.01 \\
\hline Chromium & 685.46 & 0.35 & 5.36 & 0.5 & 5.83 & 0.3 & 4.59 & 0.47 \\
\hline Cobalt & - & ND & 1.11 & $\mathrm{ND}$ & 0.05 & ND & $0 . \overline{76}$ & 0.03 \\
\hline Copper & 988.87 & $\overline{N D}$ & 37.31 & $\mathrm{ND}$ & 37.48 & $\mathrm{ND}$ & 29.22 & 0.54 \\
\hline Lead & - & ND & - & ND & - & ND & - & 0.02 \\
\hline Mercury & 315.50 & $\mathrm{ND}$ & - & ND & - & $\mathrm{ND}$ & - & 0.10 \\
\hline Molybdenum & - & $\mathrm{ND}$ & 3.09 & ND & 1.31 & ND & 1.51 & 0.12 \\
\hline Nickel & - & ND & 13.77 & ND & 12.83 & ND & 14.70 & 0.06 \\
\hline Selenium & - & ND & - & ND & - & $\mathrm{ND}$ & - & 0.18 \\
\hline Silver & - & ND & - & ND & - & ND & - & 0.02 \\
\hline Thallium & - & ND & - & ND & - & $\mathrm{ND}$ & - & 0.17 \\
\hline Vanadium & - & ND & 1.64 & 0.41 & 2.79 & 0.38 & 3.17 & 0.61 \\
\hline Zinc & 736.21 & 3.7 & 143.92 & 23.5 & 112.02 & 15.2 & 91.63 & 6.87 \\
\hline
\end{tabular}




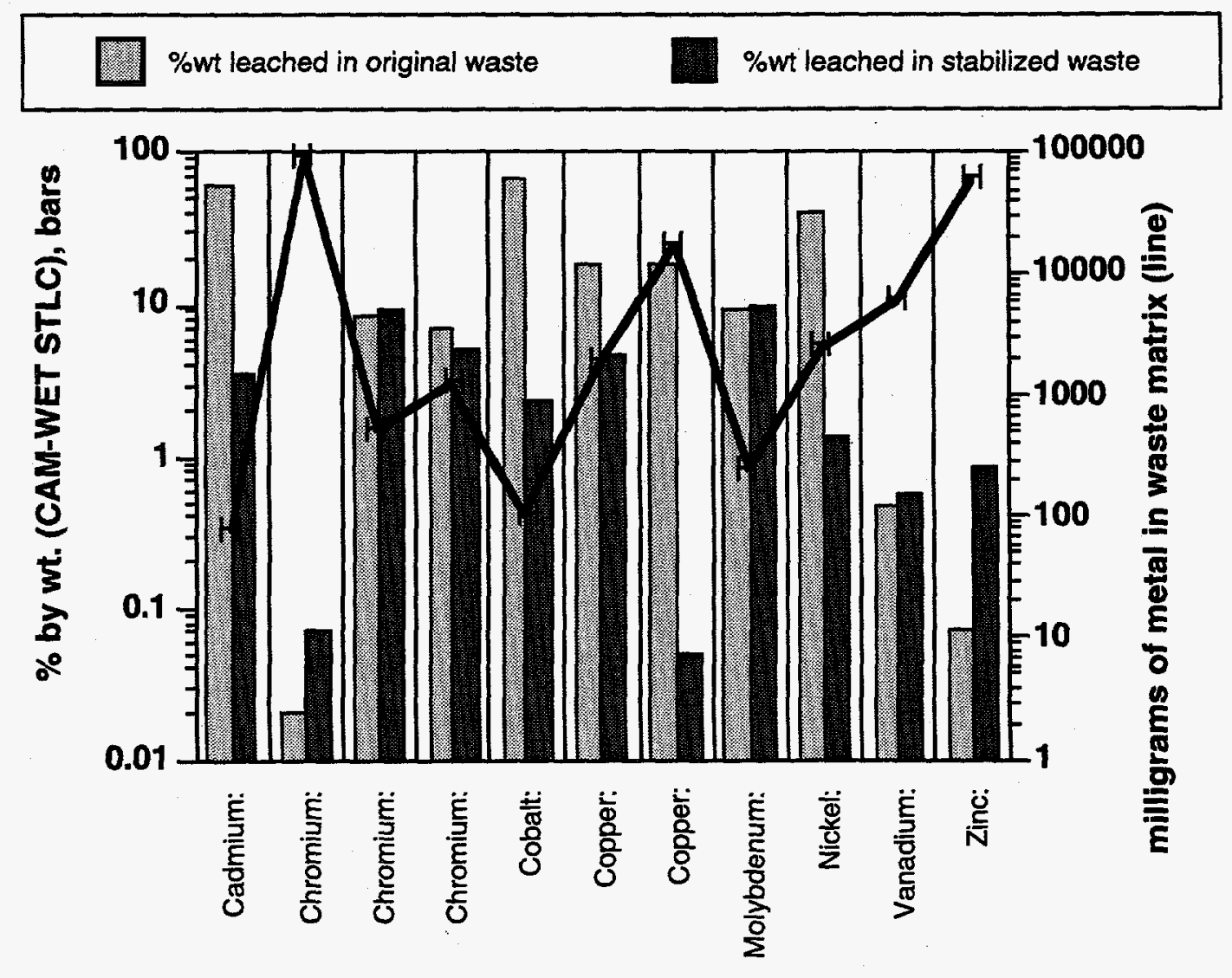

Figure 1. Direct Comparisons of Stabilization, Clay Only.

minutes, at which point the waste and additive are well mixed and reprecipitation has occurred. Next, the clay is added and mixed. This locks the reprecipitated metals in the media and physisorbs it and any other materials still free in the matrix.

Figure 2 below shows a similar chart for stabilized wastes using DTC. In every case except for barium, fixation has occurred. There was essentially no detection of nickel or silver in the leachate of stabilized wastes. This clay and DTC showed very low leachate fractions for metals except for arsenic, which does not readily precipitate with DTC and usually exists in anionic form in wastewaters. Nevertheless, some reduction in arsenic leaching was observed.

Figure 3 shows the decrease in leachate concentration with the addition of DTC. The decrease is dramatic when the DTC additive is between $3 \%$ and $12 \%$ by weight of raw waste. These wastes originally had $3,200 \mathrm{mg} / \mathrm{kg}$ nickel, $745 \mathrm{mg} / \mathrm{kg}$ copper, 429 $\mathrm{mg} / \mathrm{kg}$ zinc. Leachate concentrations for these wastes after stabilization with clay and DTC were less than $1 \mathrm{mg} / \mathrm{L}$; all stabilized wastes passed the TCLP and STLC tests. 


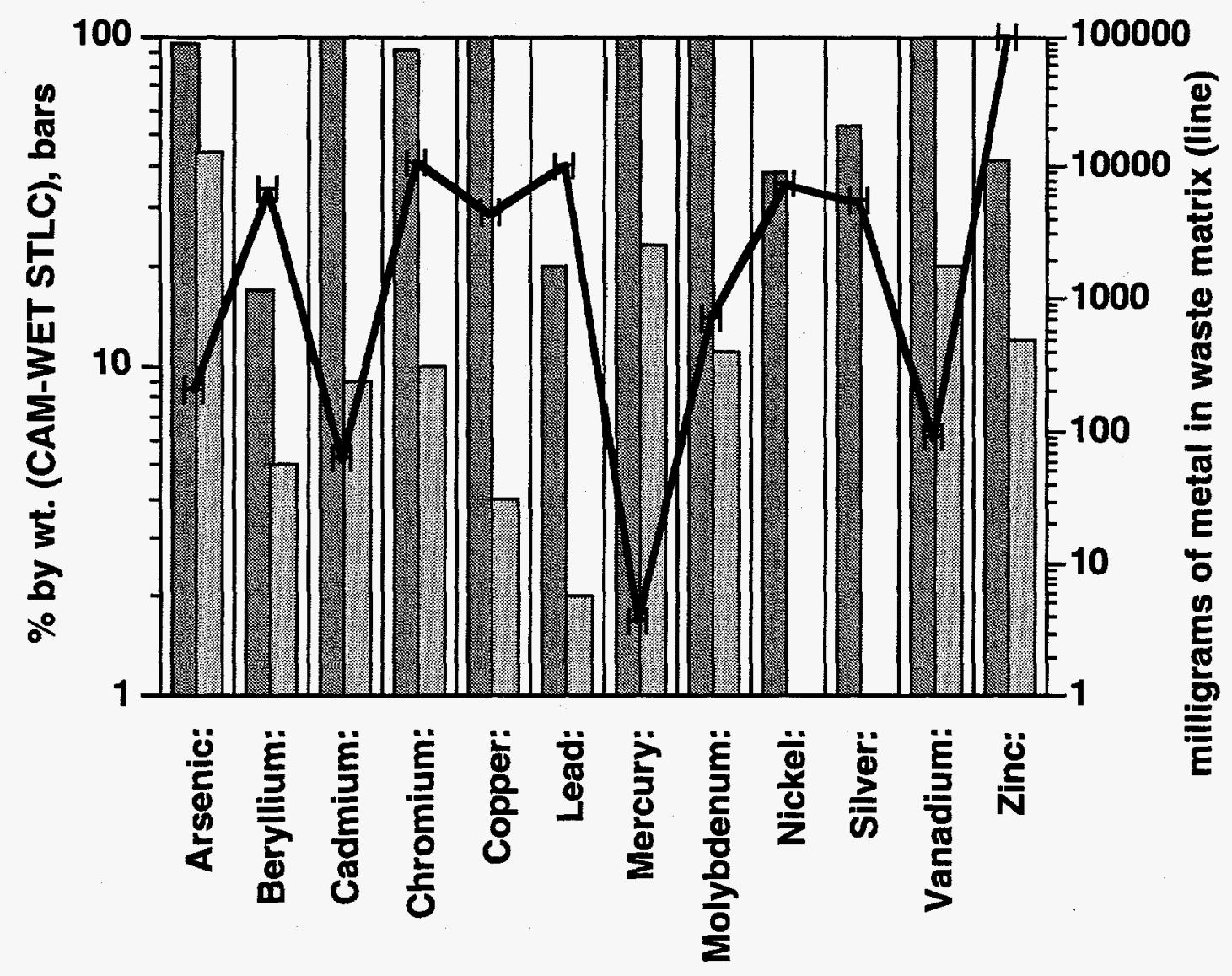

Figure 2. Direct Comparisons of Stabilization, Clay and 12\% DTC.

\section{CONCLUSION}

In many cases the use of clay alone can fix metal constituents in a waste form. In other cases, fixation must be augmented. Using clay alone when metal concentrations are high will not fixate metals enough to pass the STLC test. The $\mathrm{pH}$-insensitive additives, such as DTC or other sulfide-bearing compounds, may need to be used. Without the use of $\mathrm{pH}$-insensitive additives, metal salts become available to the leaching fluid because the interaction of the clay and the metal hydroxide is weak. With the salts available and at a $\mathrm{pH}$ of 5.0, metal hydroxide dissolves into the bulk extractant in the form of citrate or acetate salts and salt complexes. The addition of DTC at concentrations between $6 \%$ and $12 \%$ of the raw waste precipitates metals so that the clay matrix passes the STLC test. 


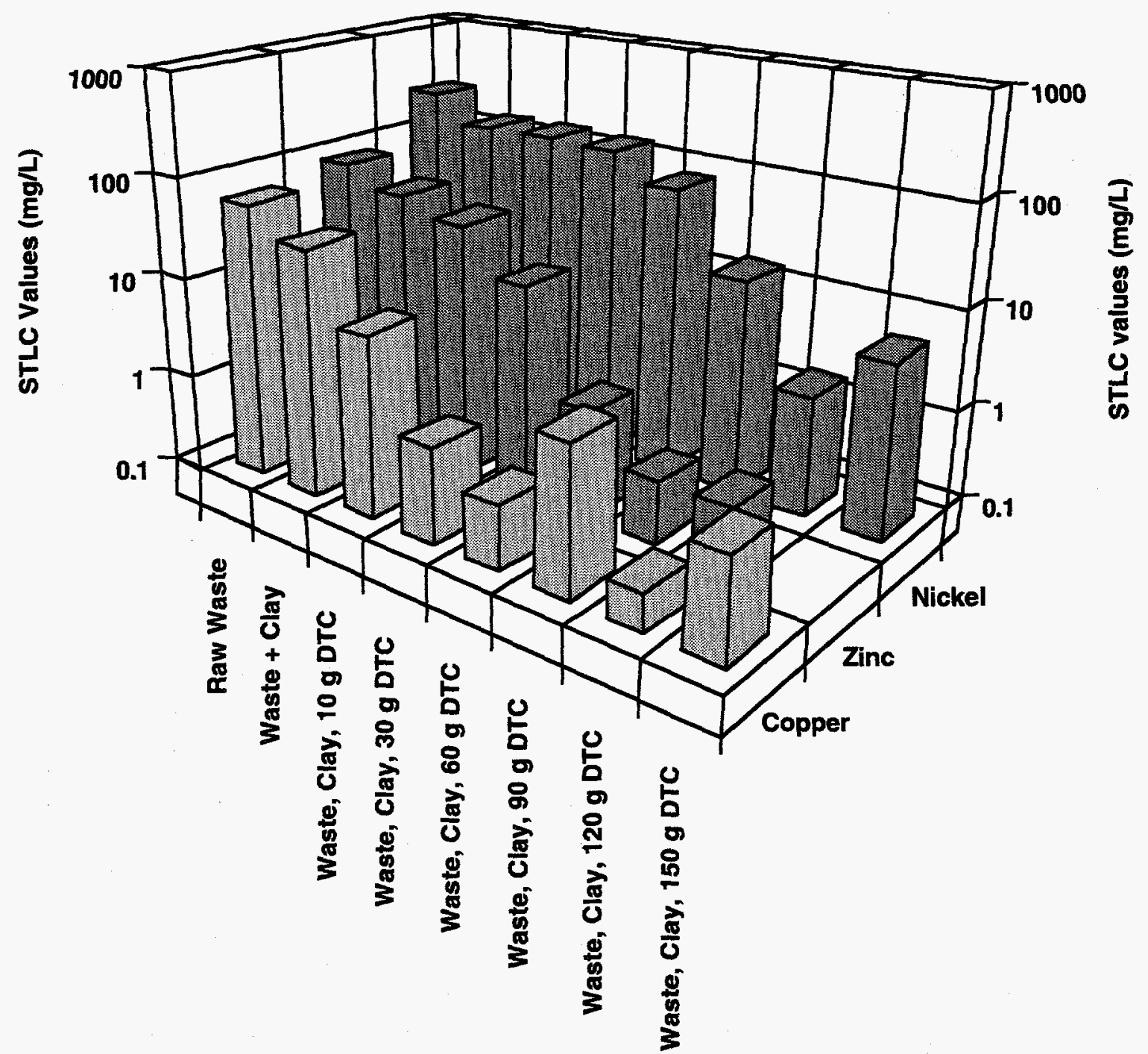

Figure 3. Comparison of STLC Values for Various Concentrations of DTC, Raw Waste, and Stabilized Waste without Additives, Based on $1 \mathrm{Kg}$ of Raw Waste.

\section{REFERENCES}

Weaver, Charles E., The Chemistry of Clay Minerals, Elsevier Scientific Publishers, New York, NY, 1975.

\section{ACKNOWLEGMENTS}

Work performed under the auspices of the U.S. Department of Energy by Lawrence Livermore National Laboratory under Contract No. W-7405-Eng-48. 